Jurnal Indonesia Sosial Teknologi: p-ISSN: 2723 - 6609

e-ISSN : 2745-5254

Vol. 2, No. 5 Mei 2021

\title{
PENURUNAN NILAI EKONOMI AKIBAT PENURUNAN NILAI KINERJA JARINGAN IRIGASI D.I. WADUK DARMA
}

\author{
Dennis Bintang Nugroho dan Saihul Anwar \\ Jurusan Teknik Sipil Fakultas Teknik Sekolah Tinggi Teknologi Cirebon \\ Email: dennisbintangnugroho@gmail.com, saihulanwar@yahoo.com
}

\section{Abstract}

Water is part of natural resources as well as part of the ecosystem. The quantity and quality at a certain location and time depends and is influenced by various things, various interests and various purposes. Along with population growth, various problems related to water or water resources have been and continue to be. The availability of water tends to decrease, but on the other hand, the need for water is increasing. In other words, the amount of water available in nature that can potentially be utilized by humans is very limited. This study aims to analyze the availability of water in the Darma reservoir area, whether the mainstay discharge, demand discharge in the Darma Reservoir Irrigation Area is fulfilled, among others, to several areas. irrigation through Kuningan / Surakatiga Weirs (525 ha), Cipikul Weirs (436 Ha), Bantarwangi Weirs (535 Ha), Citanggulun Weirs (873 Ha), Ciparigi Weirs (295 Ha), according to their needs. Knowing the condition and function of the network and irrigation building on. IN. Darma Reservoir is functioning well or not. This research also aims to determine the cost of AKNOP in DI. Darma Reservoir. This research also aims to calculate the value of economic decline. The results obtained from this study are. The mainstay discharge of the Darma Reservoir Irrigation Area from 2004 - 2014 was greater than the discharge of demand so that the discharge of needs could be met. The conditions of the Darma Reservoir Irrigation Area irrigation network from 2004 - 2014 were not functioning with an average percentage of $54.66 \%$. the building of the Darma Reservoir Irrigation Area from 2004 - 2014 was functioning. Medium this is shown by an average percentage of $59.72 \%$. From the calculations that have been done, the AKNOP costs in the Darma Reservoir irrigation area are Rp. 6,032,844,700.00 (six billion thirty-two million eight hundred forty-four thousand seven hundred rupiahs). From the calculation of the economic analysis the value of the decline in rice production in DI. Darma Reservoir from 2004 to 2014 had a maximum discharge at MT.1 of 1,573.2 tons, MT.2 of 1,283.4 tons and MT.3 of 679.8 tons. The debit of Q80 at MT.1 is 1,770 tons, MT.2 is 4,170 tons and MT.3 is 3,234 tons. The minimum debit on MT.1 is 12,939.6 tons, MT.2 is 11,101.2 tons and MT.3 is 6,085.2 tons. 
Keyword: water availability; AKNOP; economic analysis and sensitivity analysis

\section{Abstrak}

Air merupakan bagian dari sumber daya alam sekaligus juga sebagai bagian dari ekosistem. Kuantitas dan kualitasnya pada lokasi dan waktu tertentu tergantung dan dipengaruhi oleh berbagai hal, berbagai kepentingan dan berbagai tujuan. Seiring dengan pertumbuhan penduduk, berbagai persoalan yang terkait dengan air atau sumber daya air telah dan terus berlangsung. Ketersediaan air cenderung menurun namun di lain pihak kebutuhan air semakin meningkat. Dengan kata lain, air yang tersedia di alam yang secara potensial dapat dimanfaatkan manusia sangat terbatas jumlahnya. Penelitian ini bertujuan untuk menganalisis ketersediaan air di daerah Waduk Darma apakah antara debit andalan, debit kebutuhan di Daerah Irigasi Waduk Darma tercukupi di antara lain ke beberapa daerah irigasi dengan melalui Bendung Kuningan/Surakatiga (525 ha), Bendung Cipikul (436 Ha), Bendung Bantarwangi (535 Ha), Bendung Citanggulun (873 Ha), Bendung Ciparigi (295 $\mathrm{Ha}$ ), sesuai dengan kebutuhannya.Mengetahui Kondisi dan fungsi jaringan dan bangunan irigasi di. DI. Waduk Darma berfungsi baik atau tidak.Penelitian ini juga bertujuan untu mengetahai biaya AKNOP di DI Waduk Darma. Penelitian ini juga bertujuan untuk menghitung nilai penurunan ekonomi. Hasil yang diperoleh dari penelitian ini adalah. Debit andalan Daerah Irigasi Waduk Darma dari tahun 20042014 lebih besar dari debit kebutuhan dengan demikian debit kebutuhan dapat terpenuhi.Kondisi jaringan irigasi Daerah Irigasi Waduk Darma dari tahun 20042014 kurang berfungsi dengan ditunjukan prosentase rata-rata sebesar 54,66 \%.Kondisi bangunan Daerah Irigasi Waduk Darma dari tahun 2004-2014 berfungsi Sedang hal tersebut ditunjukan dengan prosentase rata-rata 59,72\%.Dari hasil perhitungan yang telah dilakukan maka didapatkan biaya AKNOP di daerah irigasi Waduk Darma sebesar Rp. 6.032.844.700,00 (enam milyar tiga puluh dua juta delapan ratus empat puluh empat ribu tujuh ratus rupiah). Dari perhitungan analisis ekonomi nilai penurunan produksi padi pada DI Waduk Darma dari tahun 2004 sampai 2014 di debit maksimum pada MT.1 sebesar 1.573,2 ton, MT.2 sebesar 1.283,4 ton dan MT.3 sebesar 679,8 ton. Di debit Q 80 pada MT.1 sebesar 1.770 ton, MT.2 sebesar 4.170 ton dan MT.3 sebesar 3.234 ton. Di debit minimum pada MT.1 sebesar 12.939,6 ton, MT.2 sebesar 11.101,2 ton dan MT.3 sebesar 6.085,2 ton.

Kata kunci: ketersediaan air; AKNOP; anlisis ekonomi dan analisis sensitivitas

\section{Pendahuluan}

Air merupakan bagian dari sumber daya alam sekaligus juga sebagai bagian dari ekosistem (Aulia \& Hakim, 2017). Kuantitas dan kualitasnya pada lokasi dan waktu tertentu tergantung dan dipengaruhi oleh berbagai hal, berbagai kepentingan dan berbagai tujuan (Alamsyah, Permana, \& Farida, 2013). Tantangan dalam penyediaan air 
adalah bagaimana mencapai ketersediaan air dengan baik dari segi kuantitas maupun kualitas (Putri, 2018). Pengendalian sumberdaya air bisa menjadi permasalahan yang berkesinambungan dari waktu ke waktu (Rahadian, 2016), dimana pada setiap interval waktu harus diambil suatu keputusan yang optimal dengan kondisi air yang berfluktuasi, kendala pada sturuktur kendali dan sistem tata air yang ada.

Bangunan sebagai infrasturktur dapat berfungsi sebagai pengendali air. (Ismawati, 2017) menjelaskan terdapat dua kategori bangunan pengendali air yaitu dimensi geometri yang tetap misalnya tanggul dan saluran, serta dimensi yang dapat berubah misalnya bendung dan waduk sehingga dapat dilakukan pengaturan.

Seiring dengan pertumbuhan penduduk, berbagai persoalan yang terkait dengan air atau sumber daya air telah dan terus berlangsung. Ketersediaan air cenderung menurun namun di lain pihak kebutuhan air semakin meningkat (Siswadi \& Purnaweni, 2011). Dengan kata lain, air yang tersedia di alam yang secara potensial dapat dimanfaatkan manusia sangat terbatas jumlahnya (Purwantini, Zakaria, \& Gunawan, n.d.). Pada kenyataanya penurunan nilai ekonomi banyak penyebabnya dari realisasi tanam yang telah dilakukan masih jauh dari rencana tanam, sehingga luas areal yang di aliri di saat debit maksimum, debit andalan dan debit minimum akan terjadi penurunan terhadap luas areal yang dialiri. Oleh sebab itu kinerja jaringan irigasi yang mengalami penurunan dari segi ketersediaan air, fungsi bangunan dan jaringan irigasi yang kurang baik dan kurangnya operasi dan pemiliharaan dapat mengakibatkan penurunan produktifitas padi atau luas areal yang dialiri mengalami penurunan. Dengan penurunan tersebut maka penurunan nilai ekonomi akibat dari turunnya kinerja jaringan irigasi (Kholiq, Aziz, Rijaludin, \& Nurjamilah, 2018).

Dalam penelitian yang telah dilakukan oleh (Irawan, 2016), faktor utama yang menyebabkan turunnya produksi adalah konversi lahan. Dari sisi produksi masalah pangan seperti meningkatnya serangan hama, terjadinya kekeringan atau banjir , rusaknya jaringan irigasi, turunnya harga pangan dan konversi lahan sawah. (Kusumo \& Hadiani, 2016) dalam penelitiannya, kurangnya dana OP serta rehabilitasi jaringan irigasi diidentifikasikan sebagai salah satu penyebab menurunnya kondisi fisik jaringan irigasi, penelitian ini juga mengkaji bagaimana mempertahankan jaringan sistem irigasi melalui rangkaian model proses yang sistematis, yakni menciptakan model penilaian kinerja, menghitung dan mendapatkan indeks kinerja di setiap komponen penilaian, mendapatkan kinerja jaringan secara umum, merekomendasikan bentuk kegiatan yang diperlukan, dan menghitung kebutuhan anggaran berdasarkan bentuk kegiatan yang direkomendasikan. Sedangkan (Hasan, 2010) dalam penelitiannya, untuk meningkatkan produksi pangan antara lain dengan ekstensifikasi pertanian dan intensifikasi pertanian. Artinya ekstensifikasi pertanian adalah usaha peningkatan produksi pengan dengan meluaskan areal tanam, dan intensifikasi pertanian adalah usaha peningkatan produksi pangan dengan cara yang intensif pada lahan yang sudah ada, antara lain dengan penggunaan bibit unggul, pemberian pupuk yang tepat serta pemberian air irigasi yang efektif dan efisien, sehingga produktifitas meningkat. 
Dari beberapa penelitan tersebut penurunan nilai ekonomi diakibatkan oleh turunnya kinerja jaringan irigasi seperti kondisi dan fungsi jaringan dan bangunan irigasi yang kurang baik, faktor lainnya penyebab penurunan nilai ekonomi adalah kodisi luas areal yang berkurang karena ketersedian air dan operasi dan pemeliharaan yang kurang juga dapa menurunkan nilai ekonomi.

Berdasarkan pada Peraturan Pemerintah Nomor 20 Tahun 2006 tersebut, irigasi berfungsi untuk mendukung produktivitas usaha tani guna meningkatkan produksi pertanian dalam rangka ketahanan pangan nasional dan kesejahteraan masyarakat, khususnya petani, yang diwujudkan melalui keberlanjutan irigasi (Indonesia, 2006). Pembangunan saluran irigasi untuk menunjang penyediaan bahan pangan nasional sangat diperlukan, sehingga ketersediaan air di lahan akan terpenuhi walaupun lahan tersebut berada jauh dari sumber air permukaan (sungai). Hal tersebut tidak terlepas dari usaha teknik irigasi yaitu memberikan air dengan kondisi tepat mutu, tepat ruang dan tepat waktu dengan cara yang efektif dan ekonomis. Kontribusi prasarana dan sarana irigasi terhadap ketahanan pangan selama ini cukup besar yaitu sebanyak $84 \%$ produksi beras nasional bersumber dari daerah irigasi (Hasan, 2005).

Adapun lokasi Daerah Irgasi yang dialiri dari Waduk Darma yaitu : 1) - D.I Surakatiga, 2) D.I Cipikul, 3) D.I Bantarwangi, 4) D.I.Ctanggulun, 5) D.I. Ciparigi. Dapat dilihat pada gambar 1 berikut:

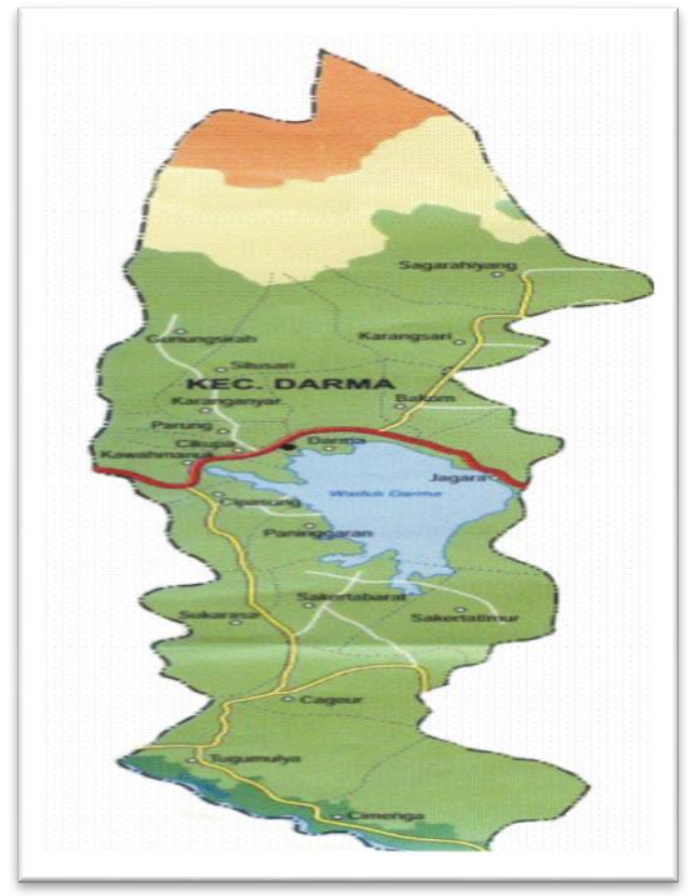

Gambar 1. Peta Waduk Darma

Tujuan penelitian ini adalah (1) Menganalisis ketersediaan air di Daerah Irigasi Waduk Darma. (2) Menganalisis AKNOP (Angka Kebutuhan Nyata Operasi Pemeliharaan) di Daerah Irigasi Waduk Darma. (3) Menganalisis Penurunan Nilai ekonomi di Daerah Irigasi Waduk Darma. 


\section{Metode Penelitian}

Menurut (Supriharyono, 2006) metode adalah suatu cara bagaimana melakukan penelitian yang baik dan benar untuk mencapai tujuan. Penelitian merupakan sebuah metode untuk menemukan sebuah pemikiran kritis (critical thinking). Menurut (Arikunto, 2003), penelitian meliputi pemberian definisi dan redefinisi terhadap masalah, memformulasikan hipotesis atau jawaban sementara, membuat kesimpulan dan sekurang-kurangnya mengadakan pengujian yang hati-hati atas semua kesimpulan untuk menentukan apakah cocok dengan hipotesis.

Pada studi ini digunakan metode deskriptif evaluatif, yaitu metode studi yang mengevaluasi kondisi objektif pada suatu keadaan yang sedang menjadi objek studi (Supriharyono, 2006). Analisis yang dipergunakan dalam penelitian ini adalah analisis deskriptif kualitatif yaitu penelitian yang bertujuan menggambarkan secara tepat sifatsifat suatu keadaan atau gejala tertentu pada lokasi penelitian. Tujuannya adalah untuk membuat gambaran secara sistematis. Sumber data penelitian terdiri dari: 1) Data utama, didapat dari buku hasil catatan Operasi Waduk Darma, data hidrologi seperti curah hujan, penguapan ( Evaporasi ); 2) Data pendukung: dari Instansi terkait seperti Dinas SDAP Kabupaten Kuningan, Dinas Pertanian dan BAPPEDA Kabupaten Kuningan, Balai Besar Wilayah Sungai Cimanuk-Cisanggarung. Pengolahan data dengan cara; 1) Menghitung data debit tersedia untuk mengetahui berapa ketersedian air daerah irigisa Waduk Darma, 2) Menghitung data kebutuhan air dengan memperhatikan rencana tanam dan realisasi tanam, 3) Menganalisis Kondisi dan fungsi jaringan dan bangunan dengan menggunakan data dari dinas PSDA Kabupaten Kuningan, 4) Menganalisis Ekonomi dengan mengunakan data debit andalan, debit maksimum dan debit minimun dibandingkan dengan luas areal yang dialiri dengan menggunakan metode grafik.

\section{Hasil dan Pembahasan}

\section{A. Analsisis dan Deskripsi}

Berikut adalah tabel resume perbandingan curah hujan, debit andalan dan debit kebutuhan.

Tabel 1. Resume perbandingan Curah Hujan, Debit Andalan, Debit Kebutuhan

\begin{tabular}{|c|c|c|c|c|c|}
\hline \multicolumn{2}{|c|}{ M3/detik } & $\begin{array}{l}\text { Curah } \\
\text { Hujan }\end{array}$ & $\begin{array}{c}\text { Debit } \\
\text { Andalan }\end{array}$ & $\begin{array}{c}\text { Debit } \\
\text { Kebutuhan }\end{array}$ & Musim \\
\hline \multirow{2}{*}{ NOP } & I & 0,566 & 0,464 & 1,358 & \multirow{7}{*}{ MT. 1} \\
\hline & II & 1,093 & 0,675 & 1,225 & \\
\hline \multirow{2}{*}{ DES } & I & 1,598 & 0,954 & 1,176 & \\
\hline & II & 1,093 & 1,234 & 1,009 & \\
\hline \multirow{2}{*}{ JAN } & I & 5,058 & 1,190 & 1,009 & \\
\hline & II & 3,379 & 1,358 & 1,013 & \\
\hline PEB & I & 2,529 & 1,115 & 0,746 & \\
\hline
\end{tabular}


Dennis Bintang Nugroho dan Saihul Anwar

\begin{tabular}{|c|c|c|c|c|c|}
\hline & II & 1,578 & 1,155 & 0,570 & \\
\hline \multirow{2}{*}{ MAR } & I & 1,032 & 1,264 & 0,639 & \\
\hline & II & 1,659 & 1,359 & 1,225 & \multirow{8}{*}{ MT.2 } \\
\hline \multirow{2}{*}{ APR } & I & 4,35 & 1,274 & 1,176 & \\
\hline & II & 1,214 & 1,370 & 1,099 & \\
\hline \multirow{2}{*}{ MEI } & I & 627 & 1,343 & 1,099 & \\
\hline & II & 2,084 & 1,303 & 1,013 & \\
\hline \multirow{2}{*}{ JUN } & I & 5,058 & 1,118 & 0,875 & \\
\hline & II & 0,000 & 0,750 & 0,715 & \\
\hline \multirow{2}{*}{ JUL } & I & 0,000 & 0,675 & 0,618 & \\
\hline & II & 0,000 & 0,735 & 0,555 & \multirow{7}{*}{ MT.3 } \\
\hline \multirow{2}{*}{ AGS } & I & 0,000 & 0,403 & 0,240 & \\
\hline & II & 0,000 & 0,295 & 0,471 & \\
\hline \multirow{2}{*}{ SEP } & I & 0,000 & 0,275 & 0,471 & \\
\hline & II & 0,000 & 0,210 & 0,379 & \\
\hline \multirow{2}{*}{ OKT } & I & 0,000 & 0,365 & 0,000 & \\
\hline & II & 0,000 & 0,449 & 0,000 & \\
\hline
\end{tabular}

Sumber : Hasil Hitungan

Dari hasil analisis terhadap perbandingan debit andalan lebih dengan debit kebutuhan Daerah Irigasi Waduk Darma dapat disimpulkan bahwa debit andalan lebih besar dari debit kebutuhan, dengan demikian kebutuhan air di Daerah Irigasi Waduk Darma dapat terpenuhi.

\section{AKNOP DI. Waduk Darma}

Perhitungan AKNOP didasarkan pada hasil pengamatan kondisi terakhir di DI. Waduk Darma. Dengan rincian AKNOP DI.Waduk Darma terdiri atas biaya operasi rutin, pemeliharaan rutin, pemeliharaan berkala dan biaya rehabilitasi. Berikut ini tabel kondisi dan fungsi jaringan dan bangunan DI. Waduk Darma: 
Tabel 2. Kondisi dan Fungsi Jaringan Irigasi DI. Waduk Darma

\begin{tabular}{|c|c|c|c|c|c|c|c|}
\hline \multirow{3}{*}{ Tahun } & \multirow{3}{*}{$\begin{array}{c}\text { Nama } \\
\text { Daerah Irigasi }\end{array}$} & \multirow{3}{*}{$\begin{array}{c}\text { Panjang } \\
(\mathrm{Km})\end{array}$} & \multirow{3}{*}{ Baik } & \multirow{2}{*}{\multicolumn{3}{|c|}{$\begin{array}{c}\text { Kondisi } \\
\text { Rusak }\end{array}$}} & Fungsi \\
\hline & & & & & & & \multirow{2}{*}{$(\%)$} \\
\hline & & & & RR & $\mathrm{RS}$ & RB & \\
\hline 2004 & Daerah & 16,705 & 12,234 & 1,804 & - & 2,667 & 73,236 \\
\hline 2005 & Irigasi & 16,705 & 12,631 & 2,384 & - & 1,690 & 75,612 \\
\hline 2006 & Surakatiga & 16,705 & 12,890 & 1,090 & - & 2,725 & 77,163 \\
\hline 2007 & & 16,705 & 13,110 & 0,950 & - & 2,645 & 78,479 \\
\hline 2008 & & 16,705 & 13,458 & 0,850 & - & 2,397 & 80,563 \\
\hline 2009 & & 16,705 & 14,115 & 0,810 & - & 1,78 & 84,496 \\
\hline 2010 & & 16,705 & 13,890 & 0,770 & - & 2,045 & 83,149 \\
\hline 2011 & & 16,705 & 14,578 & 0,987 & - & 1,140 & 87,267 \\
\hline 2012 & & 16,705 & 14,237 & 1,007 & - & 1,461 & 85,226 \\
\hline 2013 & & 16,705 & 15,003 & 1,502 & - & 0,200 & 89,811 \\
\hline 2014 & & 16,705 & 15,254 & 0,365 & - & 1,086 & 91,314 \\
\hline \multicolumn{2}{|c|}{ Jumlah rata - rata } & 16,705 & 13,764 & 1,138 & - & 0,915 & 82,392 \\
\hline 2004 & Daerah & 4,800 & 3,200 & 1,100 & - & 0,500 & 66,666667 \\
\hline 2005 & Irigasi & 4,800 & 3,400 & 0,900 & - & 0,500 & 70,833 \\
\hline 2006 & Cipikul & 4,800 & 3,300 & 0,750 & - & 0,750 & 68,750 \\
\hline 2007 & & 4,800 & 3,250 & 1,000 & - & 0,550 & 67,708 \\
\hline 2008 & & 4,800 & 3,200 & 0,850 & - & 0,750 & 66,667 \\
\hline 2009 & & 4,800 & 3,100 & 1,150 & - & 0,550 & 64,583 \\
\hline 2010 & & 4,800 & 3,050 & 1,200 & - & 0,550 & 63,542 \\
\hline 2011 & & 4,800 & 3,150 & 1,100 & - & 0,550 & 65,625 \\
\hline 2012 & & 4,800 & 3,100 & 1,050 & - & 0,650 & 64,583 \\
\hline 2013 & & 4,800 & 3,200 & 1,000 & - & 0,600 & 66,667 \\
\hline 2014 & & 4,800 & 3,400 & 0,900 & - & 0,500 & 70,833 \\
\hline \multicolumn{2}{|c|}{ Jumlah rata - rata } & 4,800 & 3,214 & 1,000 & - & 0,586 & 66,951 \\
\hline 2004 & Daerah & 5,700 & 0,900 & 2,350 & - & 2,450 & 15,789 \\
\hline 2005 & Irigasi & 5,700 & 1,500 & 2,700 & - & 1,500 & 26,316 \\
\hline 2006 & Citanggulun & 5,700 & 0,800 & 2,500 & - & 2,400 & 14,035 \\
\hline 2007 & & 5,700 & 1,200 & 2,300 & - & 2,200 & 21,053 \\
\hline 2008 & & 5,700 & 1,400 & 2,750 & - & 1,550 & 24,561 \\
\hline 2009 & & 5,700 & 0,950 & 2,600 & - & 2,150 & 16,667 \\
\hline 2010 & & 5,700 & 1,250 & 2,400 & - & 2,050 & 21,930 \\
\hline 2011 & & 5,700 & 1,630 & 2,800 & - & 1,270 & 28,596 \\
\hline 2012 & & 5,700 & 1,550 & 2,150 & - & 2,000 & 27,193 \\
\hline 2013 & & 5,700 & 1,700 & 2,600 & - & 1,400 & 29,825 \\
\hline 2014 & & 5,700 & 1,650 & 2,700 & - & 1,350 & 28,947 \\
\hline \multicolumn{2}{|c|}{ Jumlah rata - rata } & 5,700 & 1,321 & 2,532 & - & 1,847 & 23,174 \\
\hline
\end{tabular}


Dennis Bintang Nugroho dan Saihul Anwar

\begin{tabular}{|c|c|c|c|c|c|c|c|}
\hline \multirow{3}{*}{ Tahun } & \multirow{3}{*}{$\begin{array}{l}\text { Nama } \\
\text { Saluran }\end{array}$} & Panjang & \multirow{3}{*}{ Baik } & \multicolumn{3}{|c|}{ Kondisi } & \multirow{3}{*}{$\begin{array}{c}\text { Fungsi } \\
(\%)\end{array}$} \\
\hline & & \multirow{2}{*}{$(\mathrm{Km})$} & & \multicolumn{3}{|c|}{ Rusak } & \\
\hline & & & & $\mathrm{RR}$ & $\mathrm{RS}$ & $\mathrm{RB}$ & \\
\hline 2004 & Daerah & 5,900 & 2,900 & 0,900 & - & 2,100 & 49,153 \\
\hline 2005 & Irigasi & 5,900 & 3,100 & 1,100 & - & 1,700 & 52,542 \\
\hline 2006 & Bantarwangi & 5,900 & 2,700 & 1,200 & - & 2,000 & 45,763 \\
\hline 2007 & & 5,900 & 3,150 & 1,400 & - & 1,350 & 53,390 \\
\hline 2008 & & 5,900 & 3,470 & 1,750 & - & 0,680 & 58,814 \\
\hline 2009 & & 5,900 & 3,250 & 1,500 & - & 1,150 & 55,085 \\
\hline 2010 & & 5,900 & 3,600 & 1,210 & - & 1,090 & 61,017 \\
\hline 2011 & & 5,900 & 3,500 & 1,430 & - & 0,970 & 59,322 \\
\hline 2012 & & 5,900 & 3,400 & 1,500 & - & 1,000 & 57,627 \\
\hline 2013 & & 5,900 & 3,500 & 1,700 & - & 0,700 & 59,322 \\
\hline 2014 & & 5,900 & 3,600 & 1,600 & - & 0,700 & 61,017 \\
\hline \multicolumn{2}{|c|}{ Jumlah rata-rata } & 5,900 & 3,288 & 0,008 & - & 1,222 & 55,732 \\
\hline 2004 & Daerah & 2,235 & 0,953 & 0,275 & - & 1,007 & 42,640 \\
\hline 2005 & Irigasi & 2,235 & 1,117 & 0,356 & - & 0,762 & 49,978 \\
\hline 2006 & Ciparigi & 2,235 & 1,050 & 0,295 & - & 0,890 & 46,980 \\
\hline 2007 & & 2,235 & 0,893 & 0,336 & - & 1,006 & 39,955 \\
\hline 2008 & & 2,235 & 0,809 & 0,335 & - & 1,091 & 36,197 \\
\hline 2009 & & 2,235 & 0,975 & 0,309 & - & 0,951 & 43,629 \\
\hline 2010 & & 2,235 & 0,937 & 0,459 & - & 0,839 & 41,924 \\
\hline 2011 & & 2,235 & 1,215 & 0,459 & - & 0,561 & 54,362 \\
\hline 2012 & & 2,235 & 1,100 & 0,450 & - & 0,685 & 49,217 \\
\hline 2013 & & 2,235 & 1,030 & 0,605 & - & 0,600 & 46,085 \\
\hline 2014 & & 2,235 & 1,000 & 0,400 & - & 0,835 & 44,743 \\
\hline \multicolumn{2}{|c|}{$\frac{2014 \text { I }}{\text { Jumlah rata-rata }}$} & 2,235 & 1,007 & 0,389 & - & 0,839 & 45,064 \\
\hline
\end{tabular}

Sumber : Dinas PSDAP

Dari hasil analisis diatas, dapat diketahui bahwa kondisi fungsi jaringan irigasi di DI. Waduk Darma kurang berfungsi, hal tersebut ditunjukan dengan prosentase rata rata $54,66 \%$. 
Tabel 3. Kondisi dan Fungsi Bangunan Air DI. Waduk Darma

\begin{tabular}{|c|c|c|c|c|c|c|c|}
\hline \multirow{3}{*}{ Tahun } & \multirow{3}{*}{$\begin{array}{l}\text { Nama } \\
\text { Saluran }\end{array}$} & \multirow{3}{*}{$\begin{array}{l}\text { Jumlah } \\
\text { (buah) }\end{array}$} & \multirow{3}{*}{ Baik } & \multirow{2}{*}{\multicolumn{3}{|c|}{$\begin{array}{c}\text { Kondisi } \\
\text { Rusak }\end{array}$}} & \multirow{3}{*}{$\begin{array}{c}\text { Fungsi } \\
(\%)\end{array}$} \\
\hline & & & & & & & \\
\hline & & & & RR & $\mathrm{RS}$ & $\mathrm{RB}$ & \\
\hline 2004 & Daerah & 50 & 44 & - & - & 6 & 88 \\
\hline 2005 & Irigasi & 50 & 44 & - & - & 6 & 88 \\
\hline 2006 & Surakatiga & 50 & 44 & - & - & 6 & 88 \\
\hline 2007 & & 50 & 46 & - & - & 4 & 92 \\
\hline 2008 & & 50 & 45 & 2 & - & 3 & 90 \\
\hline 2009 & & 50 & 43 & 3 & - & 4 & 86 \\
\hline 2010 & & 50 & 43 & 5 & - & 2 & 86 \\
\hline 2011 & & 50 & 44 & 4 & - & 2 & 88 \\
\hline 2012 & & 50 & 45 & 3 & - & 2 & 90 \\
\hline 2013 & & 50 & 47 & 1 & - & 2 & 94 \\
\hline 2014 & & 50 & 47 & 2 & - & 1 & 94 \\
\hline \multicolumn{2}{|c|}{ Jumlah rata - rata } & 50 & $\overline{45}$ & 3 & - & 1 & 89 \\
\hline 2004 & Daerah & 60 & 12 & 44 & - & 4 & 20 \\
\hline 2005 & Irigasi & 60 & 14 & 42 & - & 4 & 23 \\
\hline 2006 & Cipikul & 60 & 18 & 38 & - & 4 & 30 \\
\hline 2007 & & 60 & 22 & 35 & - & 3 & 37 \\
\hline 2008 & & 60 & 23 & 34 & - & 3 & 38 \\
\hline 2009 & & 60 & 27 & 30 & - & 3 & 45 \\
\hline 2010 & & 60 & 28 & 30 & - & 2 & 47 \\
\hline 2011 & & 60 & 33 & 25 & - & 2 & 55 \\
\hline 2012 & & 60 & 28 & 20 & - & 2 & 47 \\
\hline 2013 & & 60 & 35 & 22 & - & 3 & 58 \\
\hline 2014 & & 60 & 36 & 20 & - & 4 & 60 \\
\hline \multicolumn{2}{|c|}{ Jumlah rata - rata } & 60 & 25 & 31 & - & 3 & 42 \\
\hline 2004 & Daerah & 69 & 36 & 21 & - & 12 & 52 \\
\hline 2005 & Irigasi & 69 & 37 & 20 & - & 12 & 54 \\
\hline 2006 & Citanggulun & 69 & 42 & 18 & - & 9 & 61 \\
\hline 2007 & & 69 & 40 & 20 & - & 9 & 58 \\
\hline 2008 & & 69 & 40 & 19 & - & 10 & 58 \\
\hline 2009 & & 69 & 43 & 16 & - & 10 & 62 \\
\hline 2010 & & 69 & 43 & 17 & - & 9 & 62 \\
\hline 2011 & & 69 & 44 & 17 & - & 8 & 64 \\
\hline 2012 & & 69 & 45 & 17 & - & 7 & 65 \\
\hline 2013 & & 69 & 32 & 20 & - & 7 & 46 \\
\hline 2014 & & 69 & 33 & 18 & - & 8 & 48 \\
\hline \multicolumn{2}{|c|}{ Jumlah rata - rata } & 69 & 40 & 18 & - & 9 & 57 \\
\hline
\end{tabular}




\begin{tabular}{|c|c|c|c|c|c|c|c|}
\hline \multirow{3}{*}{ Tahun } & \multirow{3}{*}{$\begin{array}{l}\text { Nama } \\
\text { Saluran }\end{array}$} & \multirow{3}{*}{$\begin{array}{l}\text { Jumlah } \\
\text { (buah) }\end{array}$} & \multirow{3}{*}{ Baik } & \multicolumn{3}{|c|}{ Kondisi } & \multirow{3}{*}{$\begin{array}{c}\text { Fungsi } \\
(\%)\end{array}$} \\
\hline & & & & \multicolumn{3}{|c|}{ Rusak } & \\
\hline & & & & RR & $\mathrm{RS}$ & RB & \\
\hline 2004 & Daerah & 71 & 47 & 19 & - & 5 & 66 \\
\hline 2005 & Irigasi & 71 & 48 & 18 & - & 5 & 68 \\
\hline 2006 & Bantarwangi & 71 & 49 & 17 & - & 5 & 69 \\
\hline 2007 & & 71 & 46 & 20 & - & 5 & 65 \\
\hline 2008 & & 71 & 47 & 20 & - & 4 & 66 \\
\hline 2009 & & 71 & 48 & 19 & - & 4 & 68 \\
\hline 2010 & & 71 & 50 & 17 & - & 4 & 70 \\
\hline 2011 & & 71 & 47 & 20 & - & 4 & 66 \\
\hline 2012 & & 71 & 49 & 19 & - & 3 & 69 \\
\hline 2013 & & 71 & 45 & 20 & - & 6 & 63 \\
\hline 2014 & & 71 & 49 & 18 & - & 4 & 69 \\
\hline \multicolumn{2}{|c|}{ Jumlah rata - rata } & 71 & 48 & 19 & - & 1 & 67 \\
\hline 2004 & Daerah & 43 & 19 & 17 & - & 7 & 44 \\
\hline 2005 & Irigasi & 43 & 21 & 15 & - & 7 & 49 \\
\hline 2006 & Ciparigi & 43 & 22 & 15 & - & 6 & 51 \\
\hline 2007 & & 43 & 21 & 16 & - & 6 & 20 \\
\hline 2008 & & 43 & 22 & 15 & - & 6 & 15 \\
\hline 2009 & & 43 & 24 & 13 & - & 6 & 56 \\
\hline 2010 & & 43 & 25 & 13 & - & 5 & 58 \\
\hline 2011 & & 43 & 26 & 12 & - & 5 & 15 \\
\hline 2012 & & 43 & 24 & 15 & - & 4 & 56 \\
\hline 2013 & & 43 & 24 & 16 & - & 3 & 56 \\
\hline 2014 & & 43 & 22 & 17 & - & 4 & 51 \\
\hline \multicolumn{2}{|c|}{ Jumlah rata-rata } & 43 & 23 & 15 & - & 5 & 43 \\
\hline
\end{tabular}

Sumber : Dinas PSDAP

Dari hasil analisis diatas, dapat diketahui bahwa kondisi fungsi bangunan air di DI. Waduk Darma berfungsi sedang, hal tersebut ditunjukan dengan prosentase rata rata $59,72 \%$.

\section{a. Biaya Operasi Rutin}

Untuk operasi DI. Waduk Darma diperlukan pembiayaan berupa intensif (honor atau upah) dan perjalanan dinas (bagi pengamat, juru ukur, PPA atau staf), serta biaya operasional kantor dan peralatan seperti kebutuhan ATK, bahan survey dan sebagainya. Hasil perhitungan kebutuhan biaya operasi di DI. Waduk Darma dapat dilihat pada tabel 4 berikut: 
Tabel 4. Rincian Biaya Operasi Rutin

\begin{tabular}{|c|c|c|c|}
\hline No & Uraian & \multicolumn{2}{|c|}{ Biaya (Rp) } \\
\hline 1 & Biaya Intensif & $\mathrm{Rp}$ & 40.742 .400 \\
\hline 2 & Biaya Perjalanan Dinas & $\mathrm{Rp}$ & 5.920 .000 \\
\hline 3 & Biaya Operasional Kantor dan Peralatan & $\mathrm{Rp}$ & 31.890 .000 \\
\hline & Total & $\mathrm{Rp}$ & 78.552 .400 \\
\hline
\end{tabular}

Sumber: dinas PSDP

\section{b. Biaya Pemeliharaan Rutin}

Pemeliharaan rutin adalah upaya menjaga dan mengamankan jaringan DI. Waduk Darma, agar selalu dapat berfungsi dengan baik guna memperlancar operasi dan mempertahankan keberlanjutan fungsi dan manfaat prasarana jaringan DI. Waduk Darmayang dilakukan secara terus menerus. Jenis kegiatan dan hasil perhitungan ditampilkan dalam tabel 5 berikut:

Tabel 5. Rincian Biaya Pemeliharaan Rutin

\begin{tabular}{|c|c|c|c|c|c|c|c|c|c|}
\hline \multirow{3}{*}{$\begin{array}{c}\text { No } \\
1\end{array}$} & \multirow{3}{*}{$\begin{array}{l}\text { Uraian } \\
\text { Pembersihan } \\
\text { Sampah }\end{array}$} & \multicolumn{8}{|c|}{ Kebutuhan Biaya } \\
\hline & & \multicolumn{2}{|r|}{$\begin{array}{l}\text { Saluran } \\
\text { Primer }\end{array}$} & \multicolumn{2}{|c|}{$\begin{array}{c}\text { Saluran } \\
\text { Sekunder }\end{array}$} & \multicolumn{2}{|c|}{$\begin{array}{l}\text { Saluran } \\
\text { Tersier }\end{array}$} & \multicolumn{2}{|r|}{$\begin{array}{l}\text { Tanggul } \\
\text { Pelindung }\end{array}$} \\
\hline & & $\mathrm{Rp}$ & 3.360 .000 & $\mathrm{Rp}$ & 840.000 & $\mathrm{Rp}$ & 840.000 & & \\
\hline 2 & $\begin{array}{l}\text { Pemotongan } \\
\text { Rumput }\end{array}$ & $\mathrm{Rp}$ & 25.200 .000 & $\mathrm{Rp}$ & 3.733 .300 & $\mathrm{Rp}$ & 490.000 & $\mathrm{Rp}$ & 1.120 .000 \\
\hline 3 & $\begin{array}{l}\text { Pembersihan } \\
\text { tumbuhan air }\end{array}$ & $\mathrm{Rp}$ & 20.300 .000 & $\mathrm{Rp}$ & 5.600 .000 & $\mathrm{Rp}$ & 2.940 .000 & & \\
\hline 4 & $\begin{array}{l}\text { pemeliharaan } \\
\text { tanggul }\end{array}$ & $\mathrm{Rp}$ & 11.760 .000 & $\mathrm{Rp}$ & 3.360 .000 & $\mathrm{Rp}$ & 392.000 & $\mathrm{Rp}$ & 210.000 \\
\hline \multirow[t]{2}{*}{5} & $\begin{array}{l}\text { pelumasan dan } \\
\text { pengecatan } \\
\text { bangunan air }\end{array}$ & $\mathrm{Rp}$ & 4.642 .000 & $\mathrm{Rp}$ & 4.160 .000 & $\mathrm{Rp}$ & 1.110 .000 & & \\
\hline & Jumlah Biaya & $\mathrm{Rp}$ & 65.262 .000 & $\mathrm{Rp}$ & 17.693 .300 & $\mathrm{Rp}$ & 5.772 .000 & $\mathrm{Rp}$ & 1.330 .000 \\
\hline & Total Biaya & & & & & & & $\mathrm{Rp}$ & 90.057 .300 \\
\hline
\end{tabular}

Sumber: dinas PSDP 


\section{c. Biaya Pemeliharaan Berkala}

Hasil peninjauan lapangan akan dihitung pula biaya perbaikan pintu air masing-masing. Disamping kegiatan tersebut dilakukan pemeliharaan bangunan air.

\section{Tabel 6. Rincian Biaya Pemeliharaan Berkala}

\begin{tabular}{|c|c|c|c|c|}
\hline No & Uraian & Lokasi & \multicolumn{2}{|c|}{ Biaya $(\mathrm{Rp})$} \\
\hline 1 & $\begin{array}{l}\text { Perbaikan saluran } \\
\text { (Pasangan Batu) }\end{array}$ & DI. Surakatiga & $\mathrm{Rp}$ & 211.670 .000 \\
\hline 2 & $\begin{array}{l}\text { Perbaikan Saluran } \\
\text { (Pasangan Batu) }\end{array}$ & DI. Cipikul & $\mathrm{Rp}$ & 42.333 .000 \\
\hline 3 & $\begin{array}{l}\text { Perbaikan Saluran } \\
\text { (Pasangan Batu) }\end{array}$ & DI. Citanggulun & $\mathrm{Rp}$ & 176.807 .000 \\
\hline 4 & $\begin{array}{l}\text { Perbaikan Saluran } \\
\text { (Pasangan Batu) }\end{array}$ & DI. Bantarwangi & $\mathrm{Rp}$ & 117.993 .000 \\
\hline 5 & $\begin{array}{l}\text { Perbaikan Saluran } \\
\text { (Pasangan Batu) }\end{array}$ & DI. Ciparigi & $\mathrm{Rp}$ & 205.432 .000 \\
\hline
\end{tabular}

Sumber: dinas PSDP

\section{d. Biaya Rehabilitasi}

Demi kepentingan pengaturan tata air dalam DI. Waduk Darma maka kegiatan Rehabilitasi sangat diperlukan untuk menanggulangi jaringan dan bangunan yang rusak.

Tabel 7. Rincian Biaya Rehabilitasi

\begin{tabular}{ccccc}
\hline No & Uraian & Lokasi & & Biaya (Rp) \\
\hline 1 & Perbaikan saluran & DI. Surakatiga & Rp & 1.200 .000 .000 \\
2 & Perbaikan Saluran & DI. Cipikul & Rp & 1.310 .000 .000 \\
3 & Perbaikan Saluran & DI. Citanggulun & Rp & 900.000 .000 \\
4 & Perbaikan Saluran & DI. Bantarwangi & Rp & 950.000 .000 \\
5 & Perbaikan Saluran & DI. Ciparigi & $\mathrm{Rp}$ & 750.000 .000 \\
& & & $\mathrm{Rp}$ & 5.110 .000 .000 \\
\hline
\end{tabular}

Sumber: dinas PSDP 
Dari hasil perhitungan yang telah dilakukan maka didapatkan biaya AKNOP sebesar Rp. 6.032.844.700,00 (enam milyar tiga puluh dua juta delapan ratus empat puluh empat ribu tujuh ratus rupiah). Rincian biaya AKNOP ditunjukkan dalam tabel

\section{e. Rekapitulasi Biaya AKNOP}

Tabel 8. Rekapitulasi Biaya AKNOP

\begin{tabular}{|c|c|c|c|}
\hline No & Uraian & \multicolumn{2}{|c|}{ Biaya $(\mathrm{Rp})$} \\
\hline 1 & Operasi Rutin & $\mathrm{Rp}$ & 78.552 .400 \\
\hline 2 & Pemeliharaan Rutin & $\mathrm{Rp}$ & 90.057 .300 \\
\hline 3 & Pemeliharaan Berkala & $\mathrm{Rp}$ & 754.235 .000 \\
\hline 4 & Rehabilitasi & $\mathrm{Rp}$ & 5.110 .000 .000 \\
\hline & Total & $\mathrm{Rp}$ & 6.032 .844 .700 \\
\hline
\end{tabular}

Sumber: dinas PSDP

Dari tabel dapat dilihat bahwa biaya rehabilitasi merupakn biaya paling besar $(85 \%)$ dalam rangka pengelolaan jaringan irigasi. Gambar menapilkan grafik prosentase pembiayaan AKNOP DI. Waduk Darma.

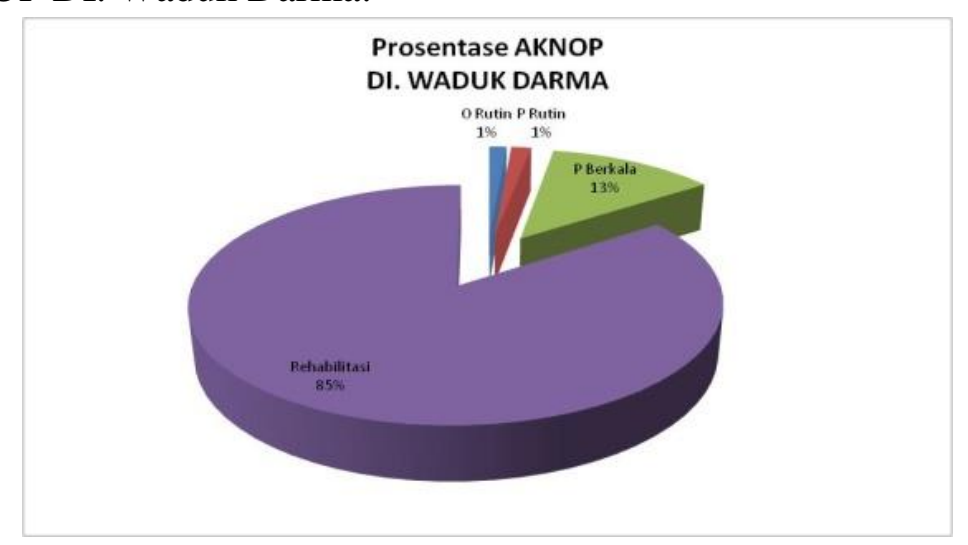

Grafik 1. Prosentase AKNOP

\section{Analisa Ekonomi}

Analisa ekonomi dibuat dalam rangka untuk mengetahui penurunan nilai ekonomi terhadap penurunan kinerja jaringan irigasi DI. Waduk Darma. Pengaruh debit yang mempengaruhi turunnya nilai ekonomi didaerah irigasi Waduk Darma. Berikut ini adalah grafik analisis penurunan nilai ekonomi terhadap debit. 


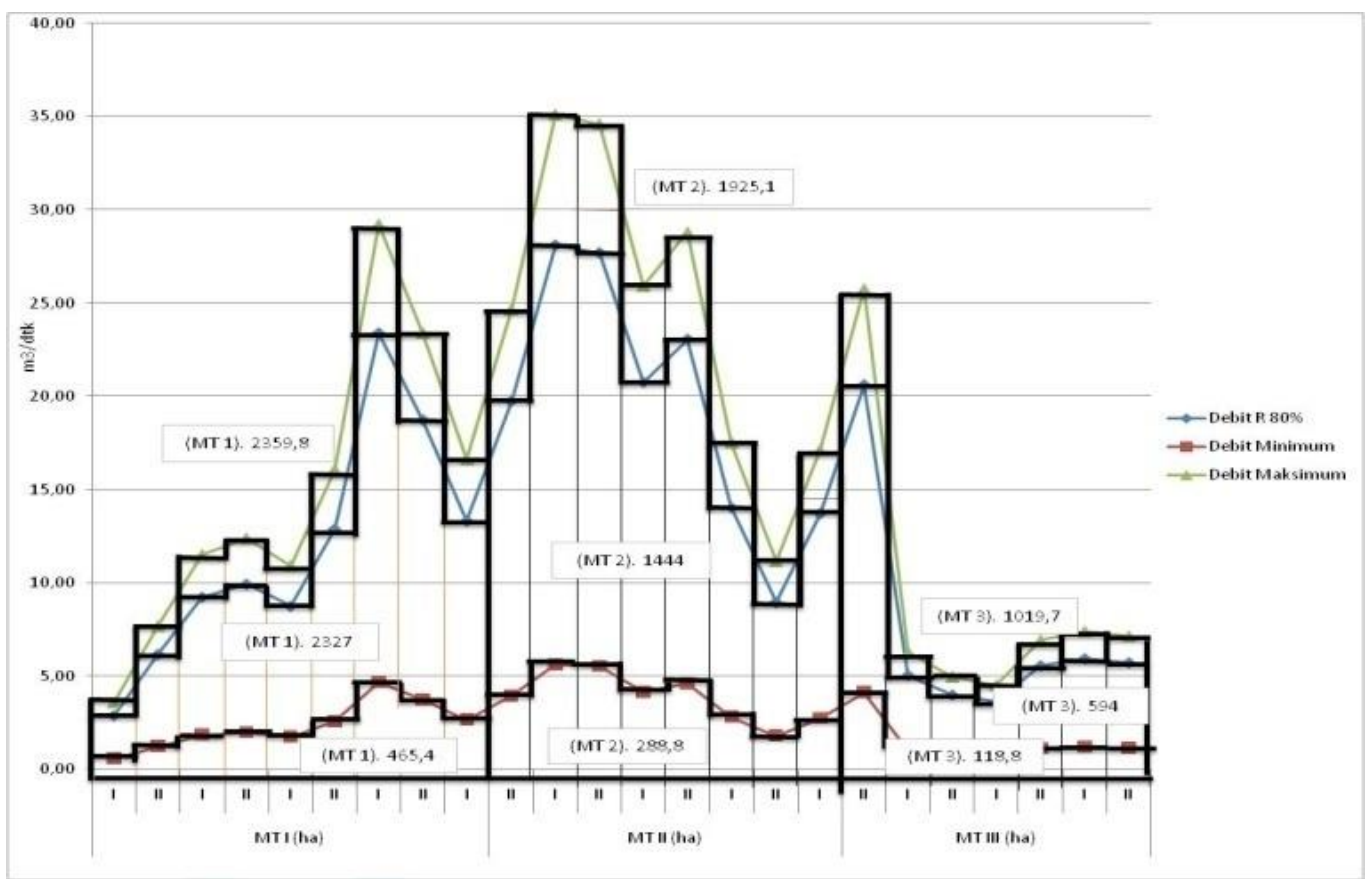

Grafik 2. Debit Maksimum, Minumun dan Q $80 \%$.

Dari grafik diatas bahwa debit minimum di MT.1 mengaliri areal sawah seluas 465,4 ha, di MT.2 mengaliri sawah seluas 288,8 ha, dan di MT.3 mengaliri sawah seluas 118,8 ha. Debit andalan di MT.1 mengaliri sawah seluas 2.327 ha, di MT.2 dapat mengaliri sawah seluas 1.444 ha, dan di MT.3 dapat mengaliri sawah seluas 594 ha. Debit Maksimum di MT.1 mengaliri sawah seluas 2.359,8 ha, di MT.2 mengaliri sawah seluas 1.925,1 ha, dan di MT.3 mengaliri sawah seluas 1.019,7 ha. Maka dapat di simpulkan bahwa penurunan nilai ekonomi terhadap debit akan mengurangi luas sawah yang dialiri, berikut penjelasan dengan menggunakan grafik 3 di bawah ini.

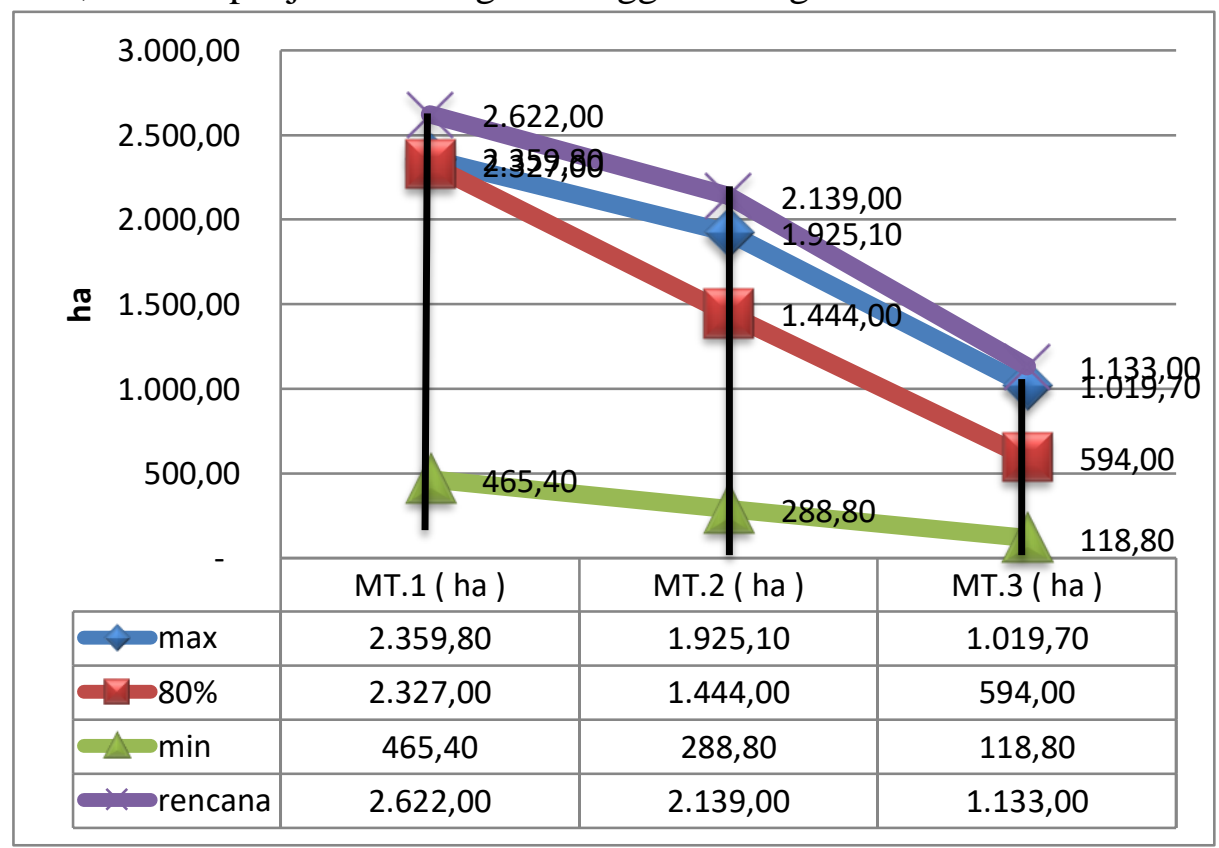

Grafik 3. Rencana Tanam, Realisasi Tanam Qmin ,Realisasi Tanam Q80\%,Realisasi Tanam Max. 
Dari grafik di atas didapatkan bahwa terjadi penurunan luas sawah yang tidak dialiri di DI. Waduk Darma. Di debit minimum terjadi penurunan luas sawah yang tidak dialiri MT.1 rencana tanam 2.622 ha - realiasi tanam 465,4 ha $=2.156,6$ ha , di MT.2 rencana tanam 2.139 ha - realisasi tanam 288,8 ha $=1.850,2$ ha, di MT.3 rencana tanam 1.133 ha - realisasi tanam 118,8 ha $=1.014,2$ ha. Di debit andalan terjadi penurunan luas sawah yang tidak dialiri MT.1 rencana tanam 2.622 ha - realisasi tanam 2.327 ha $=$ 295 ha, di MT.2 rencana tanam 2.139 ha - realisasi tanam 1.444 ha $=695$ ha, di MT.3 rencana tanam 1.133 ha - realisasi tanam 594 ha $=539$ ha. Di debit maksimum terjadi penurunan luas sawah yang tidak dialiri MT.1 rencana tanam 2.622 ha - realisasi tanam 2.359,8 ha = 262,2 ha, di MT.2 rencana tanam 2.139 ha - realisasi tanam 1.925,1 ha $=$ 213,9 ha, dan di MT.3 rencana tanam 1.133 ha - realisasi tanam 1.019,7 ha $=113,3$ ha. Berikut penjelasan di grafik

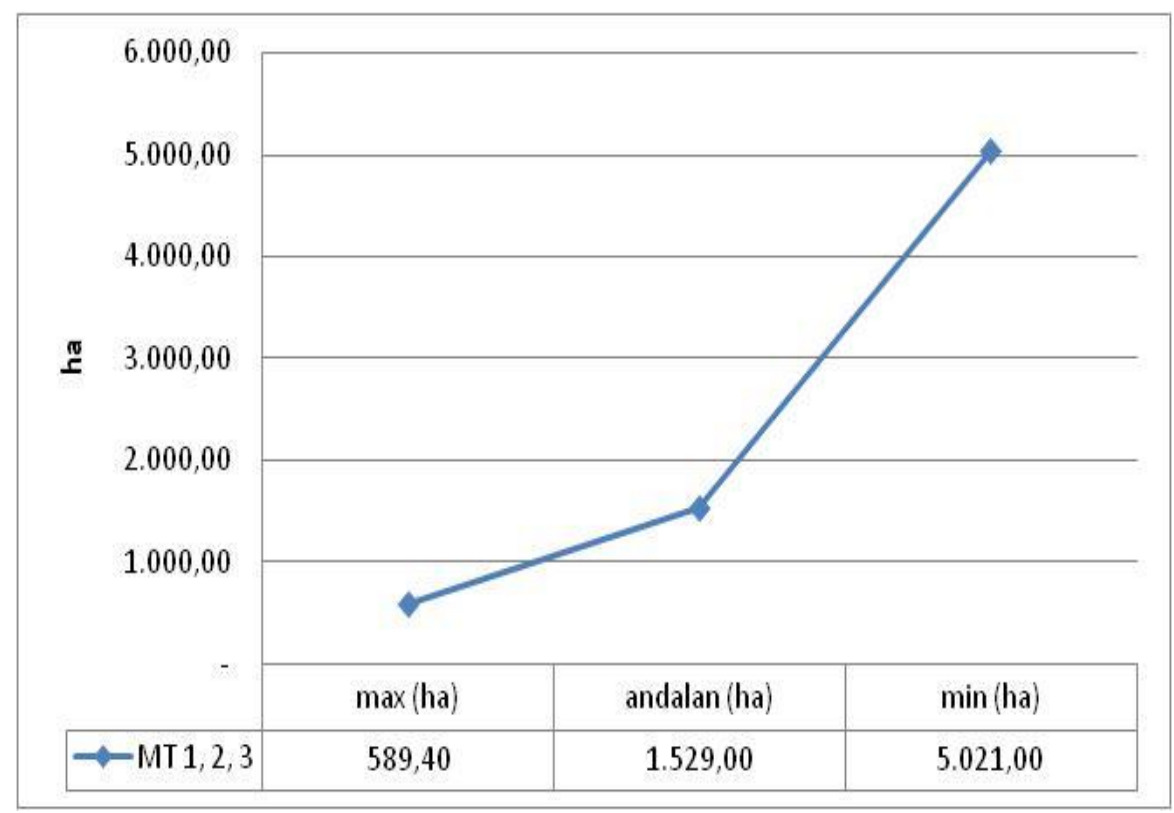

\section{Grafik 4. Grafik Sawah Total yang tidak di aliri pada debit makimum,Q80 dan minumum.}

Dari grafik diatas bahwa total sawah yang tidak dialiri di debit maksimum dari MT.1, MT.2 dan MT.3 dari tahun 2004 sampai $2014(262,2+213,9+113,3=589,4$ ha ), di debit andalan dari MT.1, MT.2 dan MT.3 dari tahun 2004 sampai 2014 ( $295+695$ + 539 = 1529 ha), di debit minimum dari MT.1, MT.2 dan MT.3 dari tahun 2004 sampai $2014(2.156,6+1.850+1.014,2=5.021$ ha $)$. Berikut grafik produksi padi dalam ton. 


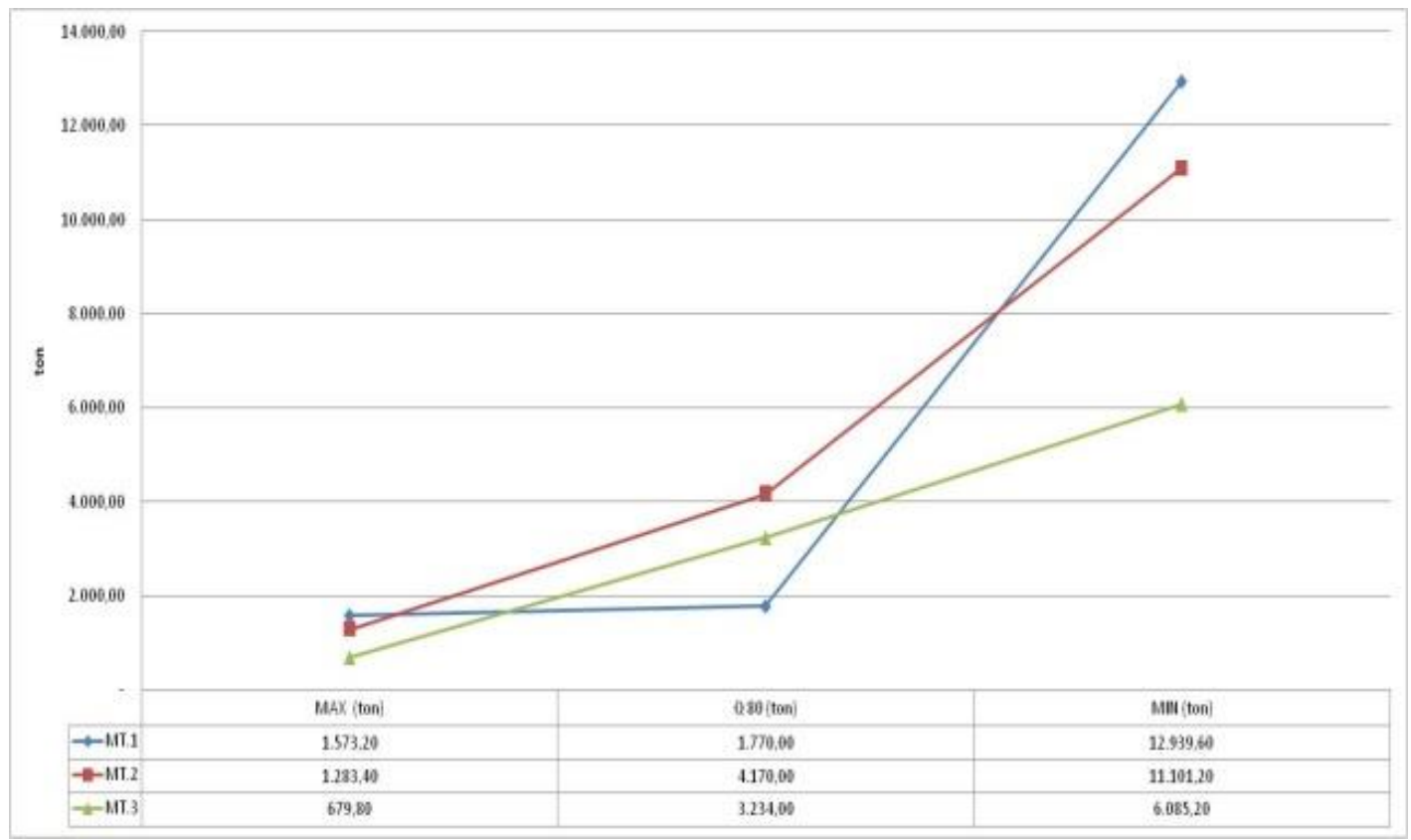

Grafik 5. Produksi Padi dalam ton terhadap debit maksimum, $Q$ so dan minimum

Dari grafik diatas dapat diketahui bahwa nilai penurunan produksi padi pada DI. Waduk Darma dari tahun 2004 sampai 2014 di debit maksimum pada MT.1 sebesar 1.573,2 ton, MT.2 sebesar 1.283,4 ton dan MT.3 sebesar 679,8 ton. Di debit Q80 pada MT.1 sebesar 1.770 ton, MT.2 sebesar 4.170 ton dan MT.3 sebesar 3.234 ton. Di debit minimum pada MT.1 sebesar 12.939,6 ton, MT.2 sebesar 11.101,2 ton dan MT.3 sebesar 6.085,2 ton.

\section{Analisa Sensitivitas}

Tabel 9. Penurunan produktivitas padi terhadap debit.

\begin{tabular}{|c|c|c|c|c|c|}
\hline \multirow{2}{*}{ Debit } & Areal yang tidak dialiri & Produksi padi per ha & Harga padi per kg & & \multirow{2}{*}{ Hasil } \\
\hline & (ha) & $(\mathrm{kg})$ & ( Rp. $)$ & & \\
\hline Maksimum & 589,40 & 6.000 & 7.000 & Rp & 24.754 .800 .000 \\
\hline$Q_{80}$ & $1.529,00$ & 6.000 & 7.000 & $R p$ & 64.218 .000 .000 \\
\hline Minimum & $5.021,00$ & 6.000 & 7.000 & $\mathrm{Rp}$ & 210.882 .000 .000 \\
\hline
\end{tabular}

Pada tabel 9 dapat diketahui bahwa penurunan produktivitas padi jika debit minimum mencapai 5.021,00 ha atau sebesar Rp. 210.882.000,00 , jika debit Q80 penurunan produktivitas padi mencapai $1.529,00$ ha atau sebesar $\mathrm{Rp}$. 64.218.000.000,00 , jika debit maksimum penurunan produktivitas padi mencapai 589,40 ha atau sebesar Rp. 24.754.800.000,00 


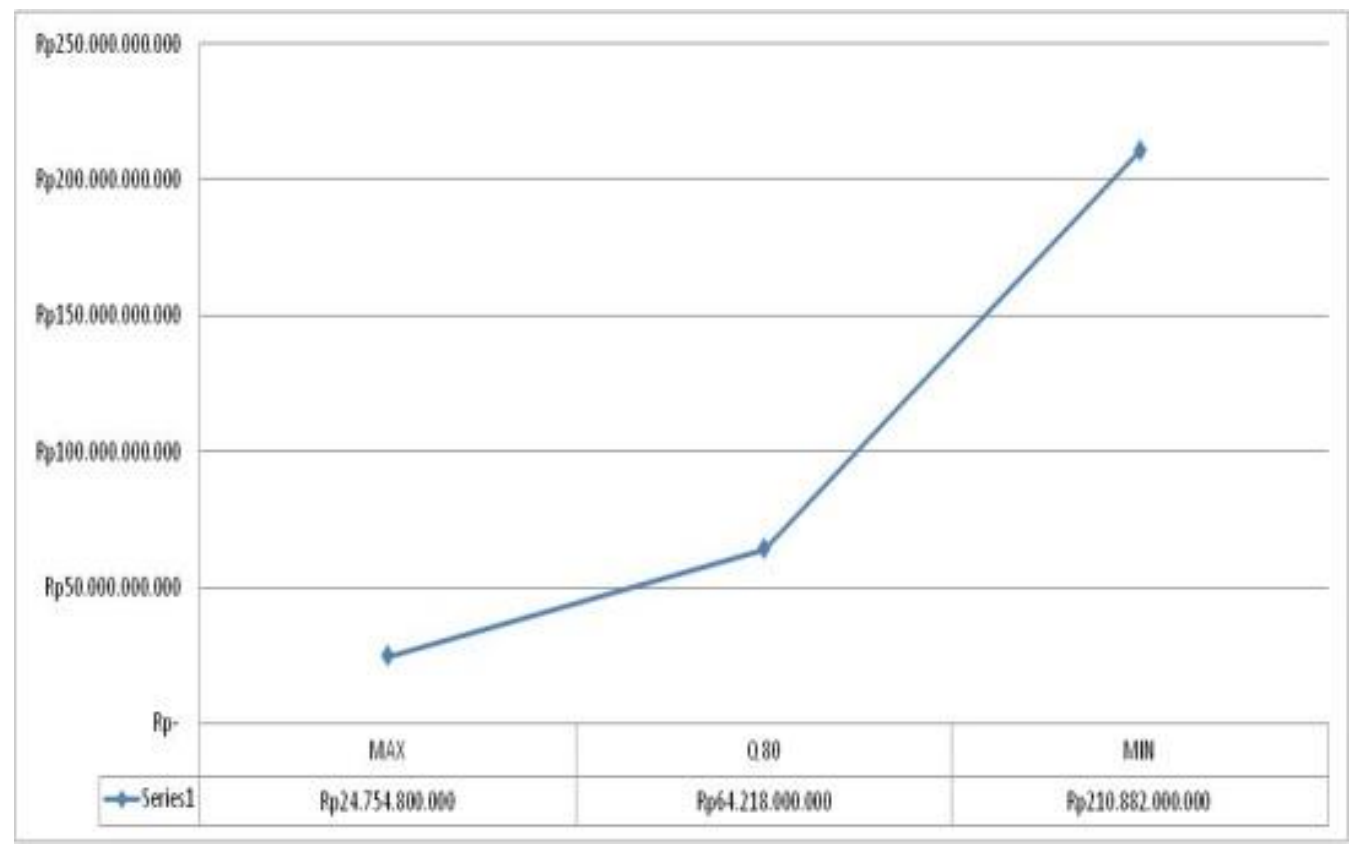

\section{Grafik 6. Penurunan Produktivitas Padi}

Grafik di atas menyatakan bahwa debit maksimum mengalami penurunan produktivitas padi yang terkecil dengan nilai sebesar Rp. 24.754.800.000,00 dan di debit minimum mengalami penurunan produktivitas padi sebesar Rp. 210.882.000.000,00

\section{Kesimpulan}

Berdasarkan hasil analisis dan pembahasan dapat disimpulkan hal - hal sebagai berikut :

1. Debit andalan Daerah Irigasi Waduk Darma dari tahun 2004 - 2014 lebih besar dari debit kebutuhan dengan demikian debit kebutuhan dapat terpenuhi.

2. Kondisi jaringan irigasi Daerah Irigasi Waduk Darma dari tahun 2004 2014 kurang berfungsi dengan ditunjukan prosentase rata - rata sebesar $54,66 \%$.

3. Kondisi bangunan Daerah Irigasi Waduk Darma dari tahun 2004 - 2014 berfungsi Sedang hal tersebut ditunjukan dengan prosentase rata - rata $59,72 \%$.

4. Dari hasil perhitungan yang telah dilakukan maka didapatkan biaya AKNOP di daerah irigasi Waduk Darma sebesar Rp. 6.032.844.700,00 (enam milyar tiga puluh dua juta delapan ratus empat puluh empat ribu tujuh ratus rupiah).

5. Dari perhitungan analisis ekonomi nilai penurunan produksi padi pada DI. Waduk Darma dari tahun 2004 sampai 2014 di debit maksimum pada MT.1 sebesar 1.573,2 ton, MT.2 sebesar 1.283,4 ton dan MT.3 sebesar 679,8 ton. Di debit $Q_{80}$ pada MT.1 sebesar 1.770 ton, MT.2 sebesar 4.170 ton dan MT.3 
sebesar 3.234 ton. Di debit minimum pada MT.1 sebesar 12.939,6 ton, MT.2 sebesar 11.101,2 ton dan MT.3 sebesar 6.085,2 ton.

6. Pada perhitungan analisis sensitivitas bahwa penurunan produktivitas padi jika debit minimum mencapai 5.021,00 ha atau sebesar Rp. 210.882.000,00, jika debit Q80 penurunan produktivitas padi mencapai 1.529,00 ha atau sebesar Rp. 64.218.000.000,00, jika debit maksimum penurunan produktivitas padi mencapai 589,40 ha atau sebesar Rp. 24.754.800.000,00. 


\section{Bibliography}

Alamsyah, R., Permana, S., \& Farida, I. (2013). Kajian Pemanfaatan Air Baku Terhadap Area Pelayanan di Kecamatan Cibalong Kabupaten Garut. Jurnal Konstruksi, 11(1).

Arikunto, S. (2003). Prosedur penelitian suatu praktek. Jakarta: Bina Aksara, 3.

Aulia, A. N., \& Hakim, L. (2017). Pengembangan Potensi Ekowisata Sungai Pekalen Atas, Desa Ranu Gedang, Kecamatan Tiris, Kabupaten Probolinggo. Jurnal Wilayah Dan Lingkungan, 5(3), 156-167.

Hasan, F. (2010). Peran luas panen dan produktivitas terhadap pertumbuhan produksi tanaman pangan di jawa timur. Jurnal Embriyo, 7(1), 15-20.

Indonesia, P. R. (2006). Peraturan Pemerintah Republik Indonesia Nomor 77 Tahun 2001 Tentang Irigasi.

Irawan, B. (2016). Konversi lahan sawah: potensi dampak, pola pemanfaatannya, dan faktor determinan.

Ismawati, S. M. (2017). Pemodelan aliran 1D pada Bendungan Tugu menggunakan software HEC-RAS. Institut Teknologi Sepuluh Nopember.

Kholiq, A., Aziz, M., Rijaludin, A., \& Nurjamilah, L. L. (2018). Evaluasi Kinerja Jaringan Irigasi Wilayah Kadipaten untuk Meningkatkan Efektivitas dan Efisiensi Pengelolaan Air Irigasi. J-ENSITEC, 4(02).

Kusumo, E. S., \& Hadiani, R. (2016). Kinerja dan Angka Kebutuhan Nyata Operasi dan Pemeliharaan Jaringan Irigasi Tambak Desa Tluwuk Kabupaten Pati. Jurnal Teknik Sipil, 1(1).

Purwantini, T. B., Zakaria, A. K., \& Gunawan, E. (n.d.). Dampak Teknologi Gerakan Penerapan Pengelolaan Tanaman (GP-PTT) Terhadap Peningkatan Produksi dan Pendapatan Petani.

Putri, V. A. (2018). Kajian Ketersediaan dan Alternatif Penyediaan Air Bersih Desa Blumbang Kecamatan Klego. Semarang: Undip.

Rahadian, A. H. (2016). Strategi pembangunan berkelanjutan. Prosiding Seminar STIAMI, 3(1), 46-56. 
Dennis Bintang Nugroho dan Saihul Anwar

Siswadi, T. T., \& Purnaweni, H. (2011). Kearifan Lokal Dalam Melestarikan Mata Air. Jurnal Lingkungan Program Studi Ilmu Lingkungan, 9(2), 63-68.

Supriharyono. (2006). Intisari Materi Kuliah Metodologi Penelitian. In Program Pascasarjana Teknik Sipil, Universitas Diponegoro, Semarang. Semarang. 